\title{
Effect of Tillage and Nutrient Management Practices on Yield and Economics of Rice (Oryza sativa) - Maize (Zea mays) Cropping System in North Bihar
}

\author{
Mritunjay Kumar, B. Mahesh Naik*, M. Karthika, Navnit Kumar and A. Kumar \\ Department of Agronomy, TCA, Dholi-843121, India \\ *Corresponding author
}

\begin{tabular}{|l|}
\hline K e y w o r d s \\
$\begin{array}{l}\text { Conservation } \\
\text { tillage, Nutrient } \\
\text { management, } \\
\text { Permanent bed, } \\
\text { SSNM, MGEY }\end{array}$ \\
\hline Article Info \\
\hline $\begin{array}{l}\text { Accepted: } \\
\text { 12 February } 2019 \\
\text { Available Online: } \\
\text { 10 March } 2019\end{array}$ \\
\hline
\end{tabular}

\section{Introduction}

In India, rice- wheat cropping system is the most predominant cropping system which has become largely mechanised, input intensive and dependence on ground water. On the other hand, rapidly rising demand for feed
In India rice-wheat cropping has been adopted widely which leads to deterioration of soil fertility and decrease in water use efficiency. In addition to these change in climate, vagaries of monsoon also leads to decrease in yields of the crop. Conservation agricultural (CA) based management practices together with nutrient management have demonstrated to produce more with less by these way it also conserve and sustain natural resources. In north eastern India maize crop is grown alternative to rice based cropping system due to variability in climatic condition and degradation of resources. Therefore, we attempted to evaluate the rice maize cropping system under conservation agriculture. The experiment was established in the year 2010 in Kharif season at Trihut College of Agriculture, Dholi, India. It was laid out in split plot design. The treatments in the main plot were the combination of tillage viz., zero tillage (ZT), conventional tillage (CT) and permanent bed (PB) whereas, in subplot were the combination of nutrient management viz., RDF, SSNM and FFP. However, rice is planted in kharif season and maize is sown in rabi season. After 7 years the results revealed that there was no significant difference in tillage treatment in rice grain yield but ZT (51.5 q/ha) showed higher yields with compare to CT (51.0 q/ha) and PB (49.3 q/ha). In Nutrient management FFP (52.7 q/ha) showed significantly higher grain yield. However, rice stalk yield and Net returns was significantly superior in ZT and FFP treatments. In maize, permanent bed and SSNM treatments showed significantly superior grain yield (92.9 q/ha), stover yield (108.8 q/ha), net returns (Rs. 83457.9) and B: $\mathrm{C}$ ratio (2.00). The maize equivalent yield (MEY) was significantly higher in permanent bed (155.5 q/ha). Whereas, in nutrient management RDF (151.3 q/ha) and SSNM (151.3 $\mathrm{q} / \mathrm{ha}$ ) showed similar results over FFP (149.8 q/ha). 
sativa L.)- maize (Zea mays L.) cropping system covers an area of about 0.53 mha in India. Moreover, expanding value addition of maize grains and the derived by-products will give a scope for improving livelihood of the farmers.

Conventional farming practices like intensive tillage and improper nutrient management are the reasons for the loss of soil fertility. This leads to inefficient use of water and nutrients leading to low productivity and input efficiency posing threat to food and environmental security. Nutrient replenishment in soil balancing nutrient extraction by crops is imperative to maintain the soil fertility. In this way, conservation agriculture is a new paradigm to achieve sustainable agricultural production. Conservation agriculture has proved to reduce input costs, environmental pollution and improve soil health (Jat et al., 2011). Proper nutrient management of rice-maize exhaustive system is mandate to reap rich harvests as their productivity mainly depends on nutrient management. Although the yield potential depends on the genotype, it can be exploited to maximum by their interaction with management factors. Apparently, Site Specific Nutrient Management System (SSNM) equips us with an opportunity for expertise management. It is a precision technology aiming to optimize the supply of soil nutrients to match the requirements of crops. Therefore, a paradigm shift from conventional to conservation tillage with proper emphasis on nutrient management will improve crop productivity, profitability and sustainability. Keeping above points in view, the present study was undertaken.

\section{Materials and Methods}

A Long-term tillage experiment was established in the year 2010 under a set of tillage, nutrient management and cropping system. The experiment was conducted at agronomical research farm, TCA Dholi, India. It lies under latitude of $25^{\circ} 99^{\prime} \mathrm{N}$ and longitude of $85^{\circ} 60^{\prime} \mathrm{E}$ and at $52.18 \mathrm{~m}$ at MSL with annual rainfall $1145.8 \mathrm{~mm}$. The mean average maximum and minimum temperature $34.2^{\circ} \mathrm{C}$ and $7.1^{\circ} \mathrm{Crespectively.} \mathrm{The} \mathrm{soil} \mathrm{of} \mathrm{the}$ experimental site was clay loam in texture, calcareous ( $\mathrm{pH}$ 8.2), high organic carbon $(0.80 \%)$.

The experiment was laid out in split plot design with three replications at fixed site. The total area of experiment site is $450 \mathrm{~m}^{2}$ and each unit is of $4.02 \times 4.20 \mathrm{~m}^{2}$ size. The treatments in the main plot were the combination of tillage viz., zero tillage (ZT), Conventional tillage (CT) and Permanent bed (PB) and cropping system viz., rice in kharif season and maize in rabi season. However, the treatment in sub plot were the combination of nutrient management viz., RDF (120-60-50 NPK kg/ha), SSNM (13075-45 NPK kg/ha) and FFP (160-75-60 NPK $\mathrm{kg} / \mathrm{ha})$. In zero tillage, the rice seeds are broadcasted uniformly throughout the plot in kharif season, while in rabi season the maize seeds were sown by opening the furrows after hand plough without any preparatory tillage operation. In case of permanent bed, the rice seeds are sown in the furrows during kharif however, in rabi the maize seeds are placed on the ridges by making a small hole with hand. In conventional tillage, the rice seedlings are transplanted after 3-4 tillage operations in puddled condition and line sowing is done in maize during rabi. Residue of every preceding crop was incorporated into the soil in case of zero tillage and permanent bed and reshaping of beds was done at the end of every cropping cycle only in case of permanent bed.

In rice and maize full dose of Pas diammonium phosphate (DAP) and $\mathrm{K}$ as muriate of potash (MOP) and $1 / 3^{\text {rd }}$ dose of $N$ 
as urea (minus the $\mathrm{N}$ added as DAP) is applied as basal dose. Remaining $2 / 3^{\text {rd }}$ of $\mathrm{N}$ is applied in 2 split doses (In case of maize two equal split doses at knee high stage and before tasseling stage when come to rice it is applied at tillering stage and panicle initiation stage). In the view, of best weed management practice spraying of non-selective, systemic herbicide like glyphosate @ 1.0 L a.i / ha in all the plots of zero tillage and permanent bed 20 days before sowing to get good germination of crops. In conventional tillage (CT) application of pre-emergence herbicide at 2-3 days after sowing and in addition to it one hand weeding is done at 30-35 days after sowing. But in case of ZT and PB one hand weeding is practicable for controlling perennial weeds. At maturity, the crop was harvested manually at the height of about $30 \mathrm{~cm}$ above the ground level during experimentation. The maize cobs were picked manually and threshed by maize sheller to estimate the grain yield. In case of rice, panicle is threshed manually and grain yield is noted. The moisture content present in the grain were estimated by moisture meter and grain moisture may be adjusted to $14 \%$. MGEY ( $\mathrm{kg} / \mathrm{ha})$ is estimated as follows

MGEY $(\mathrm{kg} / \mathrm{ha})=$ economic yield of a crop ( $\mathrm{kg} / \mathrm{ha}) \mathrm{x}$ price $(\mathrm{RS} / \mathrm{kg}$ ) of same crop

Price (RS / kg) of maize

The net returns (NR) of each treatment combination were calculated by deducting the total cost (TC) of cultivation from gross returns (GR) of respective treatments and the benefit: cost ratio was calculated by dividing the net returns with total cost of cultivation.

All the data recorded were analysed with the help of analysis of variance (ANOVA) technique (Gomez and Gomez, 1984) for split - plot design using SAS 9.3 software (SAS Institute, carry, NC). The least significant test was to decipher the main and interaction effects of treatments at 5\% level of significance $(\mathrm{P}<0.05)$.

\section{Results and Discussion}

The results from the experiment affirm that both rice and maize crops showed variable response to different tillage practices and nutrient management. Among the various tillage practices, maximum rice grain yield was obtained from ZT (51.5 q/ha) but it was not significantly superior over CT $(51 \mathrm{q} / \mathrm{ha})$ and PB (49.3 q/ha). Maximum yield in ZT may be attributed to more residue retention. This causes an increase in soil organic carbon status and leads better soil fertility. Similar results were also reported by Jat et al., (2019) wherein his experiment zero tillage direct seeded rice (ZTDSR) showed superior grain yield over permanent bed (PB) and conventional tillage (CT). Whereas in maize, PB (92.9 q/ha) gave significantly higher grain yield over ZT (86.6 q/ha) and CT (80.5 q/ha). This might have happened as it avoids the effect of water logging on maize crop which is being sensitive. Moreover, residue retention will be done which results in increase of soil fertility. Jat et al., (2013) also reported similar results that permanent bed showed $8.2-73.4 \%$ increase in grain yield over CT and no-till flat sowing. Other studies also reported higher grain yield in $\mathrm{PB}$ with compare to other treatments (Basavannepa et al., 2017). However, nutrient management treatments, FFP (52.7 q/ha) showed significantly superior rice grain yield over $100 \%$ RDF $(51.1 \mathrm{q} / \mathrm{ha})$ and SSNM (47.9 q/ha). Whereas, maize grain yields were significantly superior in SSNM (90.7 q/ha) over $100 \%$ RDF (86.5 q/ha) and FFP ( $82.8 \mathrm{q} / \mathrm{ha})$. This might be owing to fact that right rate of application matching plant requirements optimizing the nutrient use thereby improving yields. Anand et al., (2017) reported significantly superior grain yield in SSNM treatment over RDF. Kumar et 
al.(2015) and Pasuquin et al.,(2014) also observed higher grain yield in SSNM treatments with compare to other treatments. Similar results were also obtained in straw and stover yields. Harvest index is a function of grain yield to total biological yield. So it was also significantly influenced by various tillage and nutrient management treatments in maize cultivation. PB tillage practice and SSNM treatment increased harvest index to achieve a maximum of 34.7 and $35.2 \%$ respectively.

Assessment of the data in terms of economic traits is necessary for a technology to be practically successful. The above work revealed that ZT $(62261.1 \square / \mathrm{ha})$ gave significantly higher monetary net returns than PB (57573 $\square /$ ha) and CT (52885.4 $\square /$ ha) in rice crop. This might be ascribed to more yields in ZT system than PB and CT. Additionally, eliminating tillage also increases the monetary returns. Similar results were also reported by Jat et al., (2013), Hassan et al.(2005). While in maize, PB (83457.9 $\square /$ ha) gave significantly more net returns than ZT (74992.8 $\square /$ ha) and CT (66671.8 $\square / \mathrm{ha}$ ). More yields in permanent bed gave more net returns. Other studies also reported higher net returns in $\mathrm{PB}$ over other treatments (Parihar et al., (2016) and Yadav et al., (2015). Among different nutrient management treatments, SSNM gave maximum net returns than other treatments viz., $100 \%$ RDF and FFP. Here, it may be ascribed due to less fertilizer cost and more nutrient use efficiency. This was on agreement on with Shreenivas et al., (2017) and Kumar et al.(2013).

Perusal of the data showed that among the different tillage practices, higher benefit cost ratio was recorded in $\mathrm{PB}$ (2.0). these is due to Lower labour cost and mechanisation, lower fertilizer application and more yield resulted in high B: $\mathrm{C}$ ratio. These results were in accordance with Jat et al., (2012). SSNM treatment recorded that maximum benefit cost ratio than other nutrient management treatment. It improves overall profitability by saving farmers money on fertilizer providing greater returns on investment on fertilizers. These results were on close proximity with Shreenivas et al., (2017) and Kumar et al., (2013) (Table 1 and 2).

Table.1 Effect of tillage and nutrient management practices on yield and economics of rice crop

\begin{tabular}{|c|c|c|c|}
\hline Treatments & Yield (q/ha) & Stalk yield (q/ha) & Net returns( $\square /$ ha) \\
\hline \multicolumn{4}{|l|}{ Tillage practices } \\
\hline Zero Tillage (ZT) & 51.5 & 66.2 & 62261.1 \\
\hline Conventional tillage (CT) & 51.0 & 60.1 & 52885.4 \\
\hline Permanent Bed (PB) & 49.3 & 62.6 & 57573.8 \\
\hline SEm \pm & 1.77 & 2.16 & 1542.80 \\
\hline $\mathrm{CD}(\mathrm{P}=0.05)$ & NS & 4.54 & 6057.80 \\
\hline \multicolumn{4}{|l|}{ Nutrient management } \\
\hline $100 \%$ RDF & 51.1 & 59.2 & 57058.2 \\
\hline SSNM & 47.9 & 69 & 62828 \\
\hline FFP & 52.7 & 60.6 & 52834.1 \\
\hline SEm \pm & 1.22 & 1.85 & 1939.32 \\
\hline $\mathrm{CD}(\mathrm{P}=\mathbf{0 . 0 5})$ & 3.76 & 5.70 & 5975.64 \\
\hline
\end{tabular}


Table.2 Effect of tillage and nutrient management practices on yield and economics of maize crop

\begin{tabular}{|l|l|l|l|l|l|l|}
\hline Treatments & $\begin{array}{l}\text { Yield } \\
(\mathbf{q} / \mathbf{h a})\end{array}$ & $\begin{array}{l}\text { Stover yield } \\
(\mathbf{q} / \mathbf{h a})\end{array}$ & $\begin{array}{l}\text { Harvest } \\
\text { index } \mathbf{( \% )}\end{array}$ & $\begin{array}{l}\text { Net } \\
\text { returns( } \square \text { /ha) }\end{array}$ & $\begin{array}{l}\text { MEY } \\
\text { (q/ha) }\end{array}$ & $\begin{array}{l}\text { B:C } \\
\text { ratio }\end{array}$ \\
\hline \multicolumn{7}{|l|}{ Tillage practices } \\
\hline Zero Tillage (ZT) & 86.6 & 100.9 & 34.7 & 74992.8 & 151.6 & 1.8 \\
\hline $\begin{array}{l}\text { Conventional tillage } \\
\text { (CT) }\end{array}$ & 80.5 & 93.9 & 33.8 & 66671.8 & 145.3 & 1.6 \\
\hline Permanent Bed (PB) & 92.9 & 108.8 & 35.4 & 83457.9 & 155.5 & 2 \\
\hline SEm \pm & 2.13 & 2.47 & 0.19 & 2880.65 & 2.53 & 0.07 \\
\hline CD(P=0.05) & 8.35 & 9.70 & 0.75 & 11310.82 & 9.94 & 0.27 \\
\hline Nutrient management & & & & & & \\
\hline $\mathbf{1 0 0 \%}$ RDF & 86.5 & 101.3 & 34.8 & 74799.5 & 151.3 & 1.8 \\
\hline SSNM & 90.7 & 105.9 & 35.2 & 80474.4 & 151.3 & 1.9 \\
\hline FFP & 82.8 & 96.4 & 33.9 & 69848.6 & 149.8 & 1.7 \\
\hline SEm \pm & 1.19 & 1.40 & 0.23 & 1617.56 & 1.86 & 0.04 \\
\hline CD(P=0.05) & 3.68 & 4.32 & 0.71 & 4984.20 & 5.73 & 0.12 \\
\hline
\end{tabular}

Compilation of data revealed that system productivity was significantly affected by different treatments. MGEY was significantly higher under permanent bed than zero tillage and conventional tillage. This may be owed to the reason that more maize grain yield in permanent bed. Favourable soil moisture conditions, residue addition and proper establishment of maize crop in permanent bed practice benefits higher yield. Furthermore, maize being grown in rabi season provides it all benign conditions. In nutrient management practices although the SSNM produced significantly produced higher grain yield, MGEY was equal in both SSNM and $100 \%$ RDF which was superior over FFP. SSNM improves nutrient use efficiency of the crop matching between supply and demand of nutrients giving more yields.

In conclusion, conservation agriculture practices are based on minimum tillage, maximum retention of crop residues and crop rotation. By means of these principles, they influence soil biological, chemical and physical properties altering the nutrient dynamics of the soil. By taking into account this nutrient dynamics, SSNM based on targeted yield remits maximum profits. Thus, SSNM in association with conservation practise will be the best practice to reap best harvests.

\section{References}

Anand, S. R., Vishwanatha, J. and Rajkumar, R. H. 2017. Site-specific nutrient management (SSNM) using "nutrient expert" for hybrid maize (Zea mays L.) under zero tillage in Thungabhadra project (TBP) command area of Karnataka. International Journal of Current Microbiology and Applied Science 6(8): 3597-3605.

Basavanneppa, M. A., Gaddi, M. A., Chittapur, B. M. and Basavarajappa, R. 2017. Yield maximization through resource conservation technologies under maizechickpea cropping system in vertisols of Tungabhadra command project area of Karnataka. Research on Crops 18(2): 225.

Hassan, I., Baksha, K. and Maqbool, A. 2005. Impact assessment of zero tillage technology in rice-wheat system: a case study from Pakistani Punjab. Electronic Journal of Environmental, Agricultural and Food Chemistry 4(6): 1132-1137.

Jat, M.L., Saharawat, Y.S. and Gupta, R. 2011. 
Conservation agriculture in cereal systems of south Asia: nutrient management perspectives. Karnataka Journal of Agricultural Sciences, 24(1): 100-105.

Jat, R. M., Wani, S. P., Singh, P., Pathak, P., Srinivas, K., Kumar, U., Pavani, E. and Velmurgan, R. 2012. Effect of conservation agriculture on productivity and economics of different cropping systems under rainfed condition in the semi-arid tropics. $3^{\text {rd }}$ International Agronomy congress, 3: 888-890.

Jat, M. L., Gathala, M. K., Saharawat, Y. S., Tetarwal, J. P., Gupta, R. and Singh, Y. 2013. Double no-till and permanent raised beds in maize-wheat rotation of north-western indo-gangetic plains of India: Effects on crop yields, water productivity, profitability and soil physical properties. Field Crops Research, 149: 291-299.

Jat, M.R., Singh, R.G., Kumar, M., Jat, M.L., Parihar, C.M., Bijarniya, D., Sutaliya, J.M., Jat, M.K., Parihar, M.D., Kakraliya, S.K. and Gupta, R.K. 2019. Ten years of conservation agriculture in a rice-maize rotation of eastern gangetic plains of India: yield trends, water productivity and economic profitability. Fields Crops Research, 232(2019): 1-10.

Kumar, R., Karmakar, S., Kumari, S., Sakar, A. K., Dutta, S. K. and Majumdar, K. 2013. Improving productivity and profitability of the maize-wheat system in Jharkhand. Better crops, 97 (4): 2931.

Kumar, v., Singh, A. K., Jat, S. L., Parihar, C. M., Pooniya, V., Singh, B. and Sharma,
S. 2015. Precision nutrient and conservation agriculture practices for enhancing productivity, profitability, nutrient-use efficiencies and soil nutrient status of maize (Zea mays) hybrids. Indian Journal of Agricultural sciences, 85 (7): 926-30.

Pasuquin, J. M., Pampolino, M. F., Witt, C., Dobermann, A. and Oberthur, T. 2014. Closing yield gaps in maize production in southeast Asia through Site-Specific Nutrient Management. Field Crop Research, 156: 219-230.

Shreenivas, B. V., Ravi, M. V. and Latha, H. S. 2017. Effect of nutrient management approaches on maximizing productivity, nutrient uptake, soil fertility and economics of maize-chickpea cropping sequence. An Asian Journal of Soil Science, 12 (1): 1-9.

Yadav, M. R., Parihar, C. M., Jat, S. L., Singh, A. K., Kumar, D., Pooniya, V., Parihar, M. D., Saveipune, D., Parmar, H. and Jat, M. L. 2015. Effect of long-term and diversified crop rotations on nutrient uptake profitability and energetics of maize (Zea mays L.) in north-western India. Indian Journal of Agricultural Sciences, 86(6): 743-9.

Yadav, M.R., Parihar, C.M., Jat, S.L., Singh, A.K., Kumar, D., Pooniya, V., Parihar, M.D., Saveipune, D., Parmar, H.and Jat, M.L. 2016. Effect of long-term tillage and diversified crop rotations on nutrient uptake, profitability and energetic of maize (Zea mays) in northwestern India. Indian Journal of Agricultural Sciences, 86(6): 743-749.

\section{How to cite this article:}

Mritunjay Kumar, B. Mahesh Naik, M. Karthika, Navnit Kumar and A. Kumar. 2019. Effect of Tillage and Nutrient Management Practices on Yield and Economics of Rice (Oryza sativa) Maize (Zea mays) Cropping System in North Bihar. Int.J.Curr.Microbiol.App.Sci. 8(03): 13651370. doi: https://doi.org/10.20546/ijcmas.2019.803.160 